\title{
EMAPi 20 I5: Highlighting links between science and management of alien plant invasions
}

\author{
Curtis C. Daehler', Mark van Kleunen², Petr Pyšek ${ }^{3,4}$, David M. Richardson ${ }^{5}$ \\ I Department of Botany, University of Hawaii, Honolulu, HI 96822, USA 2 Ecology, Department of Biology, \\ University of Konstanz, Universitätsstraße 10, 78457 Konstanz, Germany 3 Institute of Botany, Department \\ of Invasion Ecology, The Czech Academy of Sciences, CZ-252 43 Prühonice, Czech Republic 4 Department \\ of Ecology, Faculty of Science, Charles University in Prague, Viničná 7, CZ-128 44 Praha 2, Czech Republic \\ 5 Centre for Invasion Biology, Department of Botany \& Zoology, Stellenbosch University, South Africa \\ Corresponding author: Curtis C. Daehler (daehler@hawaii.edu)
}

Received 17 June 2016 | Accepted 17 June 2016 | Published 23 June 2016

Citation: Daehler CC, van Kleunen M, Pyšek P, Richardson DM (2016) EMAPi 2015: Highlighting links between science and management of alien plant invasions. In: Daehler CC, van Kleunen M, Pyšek P, Richardson DM (Eds) Proceedings of $13^{\text {th }}$ International EMAPi conference, Waikoloa, Hawaii. NeoBiota 30: 1-3. doi: 10.3897/neobiota.30.9594

The $13^{\text {th }}$ International Conference on Ecology and Management of Alien Plant Invasions (EMAPi) was held in Waikoloa Village, Hawaii, 20-24 September 2015. EMAPi is the only international conference that focuses exclusively on alien plants; its history and broad significance were outlined by Richardson et al. (2010). During EMAPi 2015, over 200 presentations were delivered by delegates hailing from 31 countries. The presentations covered a wide range of topics in invasion biology, addressing organizational levels ranging from the gene to global patterns. Connecting science with management emerged as a unifying theme across the conference program. Commonalities emerged through lively discussions, giving new insights into research needs, management strategies, and more effective implementation of biosecurity and control. A highlight was the mid-conference field trip, where researchers, land managers, and policy makers discussed collaboration and solutions in the stimulating back drop of Hawaii Volcanoes National Park, Hakalau National Wildlife Refuge, and other conservation sites that have evolving invasive plant management strategies. Invasions were often observed in association with disturbance, but whether soil disturbance per se promotes invasion, versus above- and below-ground removal of established plants, remains as a

Copyright Curtis C. Daehler et al. This is an open access article distributed under the terms of the Creative Commons Attribution License (CC BY 4.0), which permits unrestricted use, distribution, and reproduction in any medium, provided the original author and source are credited. 
key question to be addressed for effective control and management (Leffler et al. 2016). Other themes that featured prominently at EMAPi 2015 included long-term impacts of invasions, importance of plant functional traits in invasion (Buru et al. 2016, Larrue et al. 2016) and restoration, genomics of invasions, new perspectives from China, the Cactaceae as invaders (Novoa et al. 2016), and biocontrol (Day and Winston 2016, Day and Bule 2016). Many presentations discussed new approaches for managing invasions, especially the importance of engaging all stakeholders in framing of problems associated with invasive species - examples include the voluntary code for dealing with invasive forestry trees in Europe (Brundu and Richardson 2016), and managing crossborder introduction pathways in the context of rapidly expanding global trade (Wilson et al. 2016). The full conference program and abstracts are available online (http://www. emapi2015.hawaii-conference.com/program.html) or by request to daehler@hawaii.edu.

\section{References}

Buru JC, Dhileepan K, Osunkoya OO, Firn J (2016) Comparison of growth traits between abundant and uncommon forms of a non-native vine, Dolichandra unguis-cati (Bignoniaceae) in Australia. In: Daehler CC, van Kleunen M, Pyšek P, Richardson DM (Eds) Proceedings of $13^{\text {th }}$ International EMAPi conference, Waikoloa, Hawaii. NeoBiota 30: 91-109. doi: 10.3897/neobiota.30.8495

Brundu G, Richardson DM (2016) Planted forests and invasive alien trees in Europe: A Code for managing existing and future plantings to mitigate the risk of negative impacts from invasions. In: Daehler CC, van Kleunen M, Pyšek P, Richardson DM (Eds) Proceedings of $13^{\text {th }}$ International EMAPi conference, Waikoloa, Hawaii. NeoBiota 30: 5-47. doi: $10.3897 /$ neobiota. 30.7015

Day MD, Bule S (2016) The status of weed biological control in Vanuatu. In: Daehler CC, van Kleunen M, Pyšek P, Richardson DM (Eds) Proceedings of $13^{\text {th }}$ International EMAPi conference, Waikoloa, Hawaii. NeoBiota 30: 151-166. doi: 10.3897/neobiota.30.7049

Day MD, Winston RL (2016) Biological control of weeds in the 22 Pacific island countries and territories: current status and future prospects. In: Daehler CC, van Kleunen M, Pyšek P, Richardson DM (Eds) Proceedings of $13^{\text {th }}$ International EMAPi conference, Waikoloa, Hawaii. NeoBiota 30: 167-192. doi: 10.3897/neobiota.30.7113

Larrue S, Daehler CC, Meyer J-Y, Pouteau R, Voldoire O (2016) Elevational distribution and photosynthetic characteristics of the invasive tree Spathodea campanulata on the island of Tahiti (South Pacific Ocean). In: Daehler CC, van Kleunen M, Pyšek P, Richardson DM (Eds) Proceedings of $13^{\text {th }}$ International EMAPi conference, Waikoloa, Hawaii. NeoBiota 30: 127-149. doi: 10.3897/neobiota.30.8201

Leffler AJ, Monaco TA, James JJ, Sheley RL (2016) Importance of soil and plant community disturbance for establishment of Bromus tectorum in the Intermountain West, USA. In: Daehler CC, van Kleunen M, Pyšek P, Richardson DM (Eds) Proceedings of 13th International EMAPi conference, Waikoloa, Hawaii. NeoBiota 30: 111-125. doi: 10.3897/ neobiota.30.7119 
Novoa A, Kumschick S, Richardson DM, Rouget M, Wilson JRU (2016) Native range size and growth form in Cactaceae predict invasiveness and impact. In: Daehler CC, van Kleunen M, Pyšek P, Richardson DM (Eds) Proceedings of $13^{\text {th }}$ International EMAPi conference, Waikoloa, Hawaii. NeoBiota 30: 75-90. doi: 10.3897/neobiota.30.7253

Richardson DM, Daehler CC, Leishman MR, Pauchard A, Pyšek P (2010) Plant invasions: theoretical and practical challenges. Biological Invasions 12: 3907-3911. doi: 10.1007/ s10530-010-9845-1

Wilson CE, Castro KL, Thurston GB, Sissons A (2016) Pathway risk analysis of weed seeds in imported grain: A Canadian perspective. In: Daehler CC, van Kleunen M, Pyšek P, Richardson DM (Eds) Proceedings of $13^{\text {th }}$ International EMAPi conference, Waikoloa, Hawaii. NeoBiota 30: 49-74. doi: 10.3897/neobiota.30.7502 